\title{
Black tronies in seventeenth-century Flemish art and the African presence Bernadette van Haute*
}

\begin{abstract}
* Bernadette van Haute is Associate Professor in the Department of Art History, Visual Arts and Musicology at the University of South Africa.
\end{abstract}

\begin{abstract}
In this article I examine the production of tronies or head studies of people of African origin made by the Flemish artists Peter Paul Rubens, Anthony van Dyck, Jan I Brueghel, Jacob Jordaens and Gaspar de Crayer in an attempt to uncover their use of Africans ${ }^{1}$ as models. In order to contextualise the research, the actual presence of Africans in Flanders is investigated. Although no documentation exists to calculate even an approximate number of Africans living in Flanders at that time, travel accounts of foreigners visiting the commercial city of Antwerp testify to its cosmopolitan character. A general perception of black people in those days can be extrapolated from the notebooks of Rubens and contemporary theological views. The examination of black tronies starts with the studies of Rubens, made after live models first in Italy and then in his workshop in Antwerp. By comparing various African head studies and considering them in the context of contemporary studio practices involving assistants (Van Dyck) and collaborators (Brueghel), a historically more accurate picture emerges regarding the production of such studies. Jordaens and De Crayer also made black tronies for use in history paintings, and by tracing their appearance in a select number of works it is possible to distinguish their respective models. Assumptions regarding the extent of the influence of Rubens are thus put in perspective while giving credit to contributions made by Van Dyck, Jordaens and De Crayer to the study of African people.
\end{abstract}

\section{Introduction}

There is the assumption that there were very few Africans in Antwerp in the seventeenth century and that artists were thus confined to one model, namely the black man painted by Rubens in his famous Four Studies of the Head of a Black Man. ${ }^{2}$ D'Hulst (1982:110) first remarked that 'dark-skinned natives of the Maghreb cannot have been very numerous in Antwerp at that time, and it may be that all three masters [Rubens, Van Dyck and Jordaens] used the same model'. More recently Kolfin (2008:78) made a similar statement:

\begin{abstract}
Having a genuine black model at one's disposal must have been a great event artistically speaking. ... at least two other painters from Rubens' circle made oil sketches of this man which seem to have been inspired by Rubens' study heads: Jacob Jordaens ... around 1620 and Gaspar de Crayer ... in the mid-1620s. Although Jordaens' studies are definitely of the same man, this is harder to ascertain in the case of De Crayer's work.
\end{abstract}

Adding to this point of view, Massing (2011:1) states that Rubens painted the same person four times in the Brussels painting, 'suggesting that people of African origin were still rare in Antwerp at the time'. In order to verify these claims, I set out in the first place to find out more about the presence of African people in Flanders and how they were perceived in the seventeenth century. Evidence of artists' direct contact with people of African origin exists in the form of tronies or head studies, hence the main focus of this article is on the examination of head studies by Peter Paul Rubens, Anthony van Dyck, Jan I Brueghel, Jacob Jordaens and Gaspar de Crayer. The production of tronies was a studio practice which involved not only the master of the workshop but also pupils, assistants and collaborators. By comparing the tronies and considering them in their culturalhistorical context, I aim to trace some form of interaction between the different artists and to draw conclusions regarding their use of African models.

\section{Presence of Africans in Flanders}

According to Debrunner (1979:34), soon after the Portuguese had started exploring the African continent in search of trading opportunities, the first African slaves were shipped to Portugal in 1436. The Portuguese traded in return with goods obtained from the Spanish possessions of the Netherlands. This explains the early presence of Africans travelling with these merchants in Flemish trading cities such as Ghent, Brussels, Antwerp and Bruges (Schreuder 2008:23). Two well- 
known artworks are often cited as evidence of the presence of black people in Flanders in the early sixteenth century. They are the Portrait of Katherina (1521) drawn by Albrecht Dürer ${ }^{3}$ and the Portrait of an African Man (1520-25), painted by the Haarlem artist Jan Mostaert ${ }^{4}$ while in Antwerp or Mechelen.

The Portuguese maintained a brisk trade with Antwerp in the course of the sixteenth century. African products that were shipped to Lisbon were mostly transported to Antwerp, the main distribution centre for African raw materials, turning the city into the most powerful colony of Portuguese merchants (Denucé 1937:42). The shipping company of the Portuguese merchant De Haro, for example, first established in Lisbon, became permanently located in Antwerp (Denucé 1937:38). The Antwerp firm Ximenes, which formed a partnership with the family branch in Lisbon, became one of the most influential businesses in Western Europe. The last male representatives of the Antwerp branch, namely Duarte, Manoël and Gonçalo Ximenes d'Arragon, resided in a spacious palace on the Meir (Denucé 1937:50-57). These foreigners brought with them their families, fashions and customs, including their slaves and servants. According to Debrunner (1979:57),

[i]t has been stated that in that harbour [Antwerp] was the greatest European colony of Africans after Lisbon. ${ }^{5}$ Numerous baptisms of black children are recorded; e.g. on October 13 1591, 'an African child in the family of Henrique Diaz Milan.' There are also quite a number of documents available concerning enfranchisements of Africans. Thus in 1566 Antoine Rodrigues was liberated, 'an African from Cape Verde who had stayed for 24 years in Antwerp'. ${ }^{6}$

Some of the Africans staying in Antwerp were 'free blacks' employed as servants; others were slaves owned by Spanish and Portuguese masters (Goris 1923: 541-544). ${ }^{7}$ Although Antwerp did not take part in the slave trade (Denucé 1937:79) and the city's law actually prohibited enslavement (Blakely 1993:226), the judiciary in Antwerp was not always consistent in its attitude towards slavery. Africans who were baptised were not officially allowed to be enslaved. And if slaves petitioned the authorities, they had to be freed. In practice, however, it was entirely possible to keep and sell slaves (Haarnack and Hondius 2008:90-91). Whether free or enslaved, these black servants had a very low social status. To have an African servant became a fashion which, according to Debrunner (1979:92), proved particularly popular in the Spanish Netherlands in the sixteenth century.

The Duke of Alva's introduction of two new taxes in $1571^{8}$ was the deathblow for the Antwerp trade, as it caused a great number of merchants to leave the city (Denucé 1937:82). The decline was gradual and inexorable until the Treaty of Munster in 1648 when the northern Netherlands gained its independence and took control of international trade relations. Dutch colonial expansion explains the growing presence of Africans in the northern Netherlands in the course of the seventeenth century (Massing 2011:229). In Antwerp, on the other hand, despite its collapse as a major economic centre, the first decades of the seventeenth century were still marked by the fortunes made in the previous century. Although their numbers had dwindled considerably, there was still a large contingent of southern European merchants. The members of the Antwerp branch of the Ximenes firm, for example, were still running a lucrative business and made a generous donation to the Church of Our Lady in 1619 (Denucé 1937:57).

This scenario is confirmed by Goris (1940), who compiled a picture of Antwerp based on travel accounts written by foreign visitors to the city in the seventeenth century. He states that the sons of Spanish merchants and officials who married in Antwerp filled important positions in the magistrate while some Portuguese Jews kept the diamond industry going. These merchants and magistrates were wealthy and lived in palatial homes with lush gardens (Goris 1940:49). The Portuguese merchant Duarte, ${ }^{9}$ for example, whose father dominated the diamond and pearl industry by the beginning of the seventeenth century, owned one of those splendid houses where foreign dignitaries would reside during their visit to Antwerp (Goris 1940:119). Apart from living a princely lifestyle, he also built up an impressive art collection. Constantijn Huygens was a close friend of the Duartes and together they would visit painters to buy artworks (De Clippel 2006:24; Goris 1940:120). Duarte's neighbour, the merchant De Castro, also received royal guests (Goris 1940:120). 
A telling remark regarding the Spanish presence in Antwerp was made by Johann Wilhelm Neumayr, who formed part of the entourage of Duke Johann Ernst of SaxenWeimar on his visit to Antwerp in 1613. He seemed to be quite overwhelmed by the many Spanish in Antwerp, commenting that instead of merchants and traders, nothing but Spaniards walked its streets with typical bravado (Goris 1940:66). ${ }^{10}$ As mentioned before, these foreigners brought with them their black servants or slaves who were often sold and even bestowed on new owners (Massing 2011:233). Hence black servants - men, women and children - probably also became a familiar sight in the households of wealthy Antwerp citizens.

One such black page is depicted in the painting of The Cabinet of the Art Lover $(1621)^{11}$ attributed to Hieronymus II Francken, demonstrating that the notion of the African servant was not strange. Similarly, in a work painted by Sebastiaen Vrancx of Winter Pastime on the Scheldt at the Kranenhoofd in Antwerp (1622), ${ }^{12}$ a black servant can be observed. The painting offers a panoramic view of the city of Antwerp from the frozen Scheldt River on which people walk and play. In the foreground on the left a horse-drawn carriage has come to a standstill and a woman in a blue dress is stepping out, aided by a black servant dressed in red. Although the documentary value of such genre paintings is questionable, the imagery is at least partly shaped by reality, hence the African presence in Antwerp is not imaginary.

\section{The seventeenth-century perception of Africans}

Despite the presence of African people in Antwerp, knowledge of the African continent and its peoples was nevertheless limited in the southern Netherlands. The concept of 'Ethiopia' was geographically vague and could mean India as well as Africa (Kaplan 2010:107; McGrath 2008a:94). Since the notion of 'race' as we understand it today did not exist in the seventeenth century, it would be historically inaccurate to examine the perception of Africans from a racial perspective (Erickson 1993:499-500). The European perception of black Africans has been construed as a function of social and aesthetic fashion - the ornamental display of the exotic - as well as of theology
(Erickson 1993:501-502). Given the strong impact of the Counter-Reformation in Flanders at that time, religious values may well have played a crucial role in the construction of an African identity in the minds of Flemish artists.

From a religious point of view, Europeans had a positive image of Ethiopia as it was ruled by Christian kings (Schreuder 2008:22). Various biblical narratives, such as the one of Philip the Evangelist baptising the Ethiopian Eunuch (Acts 8:27), led to the theological association of Ethiopian blackness with openness to the Christian message. ${ }^{13}$ Black people were seen to represent the Gentiles 'the people who, unlike the Jews, were ready to recognise Christ, coming to him even from the remotest lands' (McGrath 2008b:52). The prime protagonist of this notion was the black Magus who had come from afar to adore the Christ child and accept the Christian faith in order for his spiritual darkness to be lightened by Christ (McGrath 2008b:266). Hence 'theology allowed for the idea that Ethiopian blackness was a signal not so much of "otherness" as of openness to the Christian message' (McGrath 2008b:52). Since the theme of the Adoration of the Magi remained a popular choice for Flemish altarpieces in the first half of the seventeenth century, ${ }^{14}$ artists had to find ways to visualise this idea convincingly for the faithful.

The reason why Flemish artists showed an interest in Africans was, in the first place, determined by iconographic conventions. History painters of biblical, mythological and allegorical subject matter were careful to adhere to the respective literary sources and existing pictorial traditions. They were thus not interested in the anthropology of different ethnic groups ${ }^{15}$ - i.e., their life and identity in their places of origin - or in the new roles of Africans in Flemish society. Whereas they may have felt a generalised cultural uneasiness towards Africans, ${ }^{16}$ artists seem to have regarded them solely as players in historical scenes and other stories. ${ }^{17}$ The main pursuit of the artists was then to represent their African subjects as realistically as possible in terms of physical appearance.

Seventeenth-century observations concerning the physical characteristics of black Africans were mostly based on classical distinctions (Massing 2011:396). ${ }^{18}$ According to Meganck (2007:57), Rubens' studies of 
human physiognomy were derived from the pseudo-Aristotelian Physiognomonica which

distinguished three paths to knowledge of the human race: the observation of the affects or emotions, national character and - in particular - the comparison of man and animal. The goal of physiognomy was the determination of inner character on the basis of human exterior (posture, color, bodily proportions and especially facial features).

Rubens seems to have had a certain admiration for the robust physique of dark-skinned people. In his discussion of the antique figure of Hercules Farnese, Rubens (1773:4) observed that the Ethiopians, the Africans and the Turks somehow resemble the celebrated statue in terms of physical proportions (Meganck 2007:59). Not quite admitting that they share 'the same strength' of Hercules, he commented that 'their body parts are more or less alike. They have, for example, the same round head, curly hair like that of the bull, the neck short and muscular, broad shoulders, etc.' ${ }^{19}$ In the above quotation, skin colour is mentioned as another exterior factor determining inner character. Yet no documents have survived that mention Rubens' specific ideas regarding the skin colour of Africans.

According to Erickson (1993:5), an explanation of the early perception of black Africans grounded in exoticism or theology minimises two key aspects, namely 'the fashioning of power relations and the concomitant anxiety and ambivalence'. ${ }^{20}$ Whereas anxiety may be too strong a term to describe the attitude towards Africans in Flanders, it was characterised by a definite ambivalence which persisted throughout the centuries (Blakely 1993:276). A simple example may illustrate this. The generally positive opinion of the black physique was restricted to the body: the African face was seldom seen as beautiful (Kolfin 2008:72) because its features were not congruent with stereotypical notions of beauty according to the canons of Western classicism. Rubens identified another negative characteristic based on his association of hair with courage. He stated: 'Those with very woolly hair are cowardly; this applies to the Ethiopians. Since then, excessively woolly hair betokens cowardice, hair which curls at the ends, tends towards stout-heartedness; witness the lion among others' (Meganck 2007:64, note 82). Thus in the eyes of Rubens, Africans were well built but neither strong nor courageous men.

The Flemish view of Africans was thus ambivalent, but it is this very variability which allowed the African subject to be portrayed in different roles, be it as a king, a soldier or musician, a satyr, a servant or a saved soul. In his role as black Magus the African would show an attractive physique and dazzle in a sumptuous, exotic outfit. As a servant, ${ }^{21}$ greater emphasis would be placed on gestures and facial expressions underscoring his servitude. This role division stresses the primacy of social status, as determined by lineage, over skin colour.

\section{The tronie in the Flemish studio}

The term tronie in old Dutch designates a study, drawn or painted, of a facial expression (Van Hout 2012:35). Studies of heads were made and collected by seventeenth-century artists not as portraits, but as examples of certain types of faces - of a child, woman or man, young, mature or old, etc. - and facial expressions depicting various psychological states. Moreover, by representing the model from various angles these studies could be used for multiple purposes. Head studies were created for use in paintings of different kinds of subject matter. Their main contribution was to imbue the figures with a strong character, which means that they were only used when the artwork was nearing completion (Joubert et al. 2012:27).

A typical example of a tronie is the study of a black child in Two Black Heads (1) painted in the first half of the seventeenth century. ${ }^{22}$ The rather roughly sketched study shows two views of the bust of a black child. On the left the child is depicted in profile looking to the left. On the right the child's body is positioned at an angle but its head is turned sideways to look straight at the viewer. The facial expression is rendered with great subtlety, oscillating between serenity and sadness. Judging by the white collar and the buttoned jacket the child is probably a boy who was employed as a page in a rich Flemish household. The artist may have made the study of this young model for use in paintings of the Adoration of the Magi whose entourage often included children. In view of the fact that the number of surviving head studies of women and children is very limited 


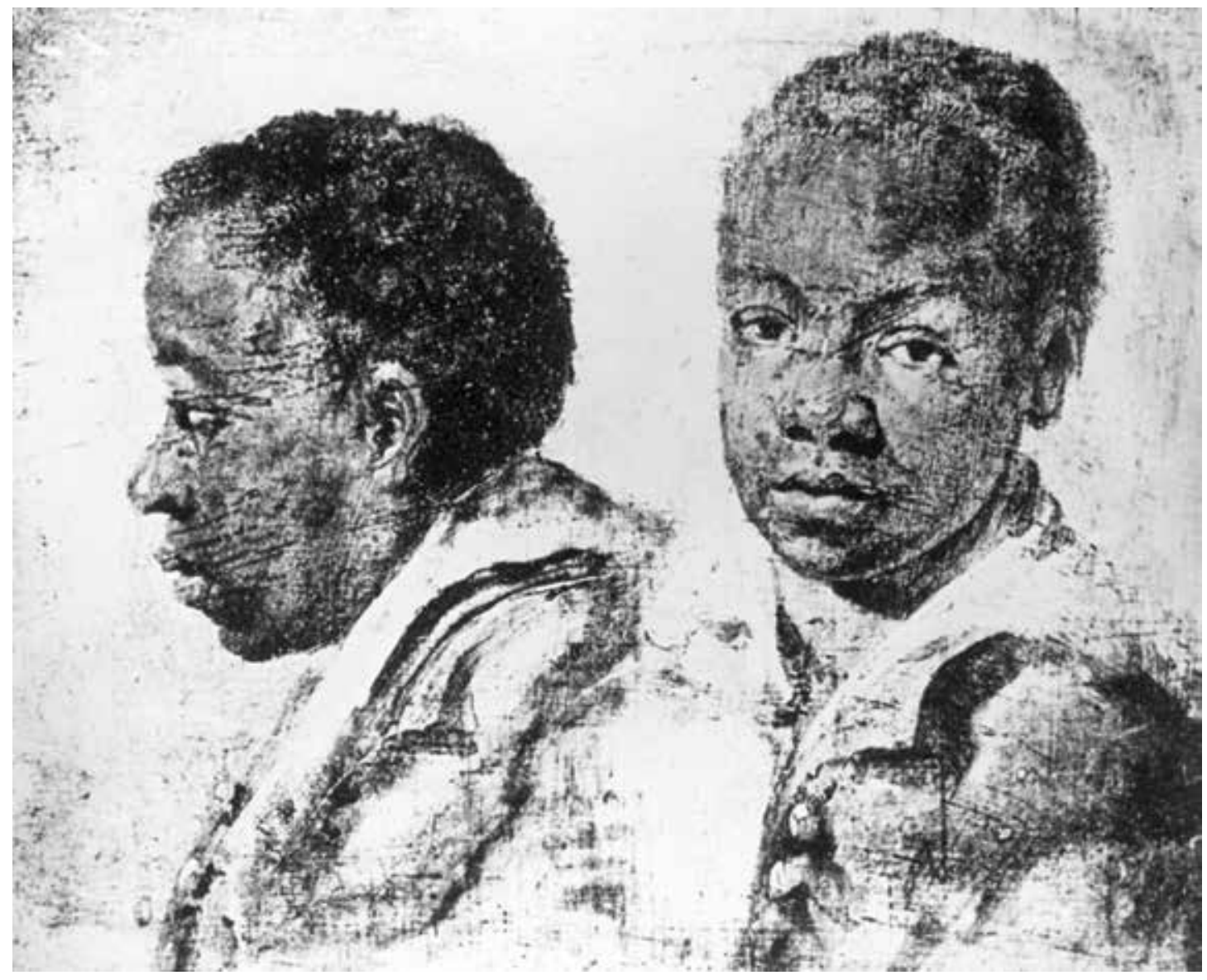

1 Flemish School, Two Black Heads. Oil on canvas, 16.5 x $20.3 \mathrm{~cm}$. Formerly Paris, Collection Lady Mendl (Elsie de Wolfe); present location unknown.

(Van Hout 2012:42), this tronie provides important evidence regarding the presence of black children in the southern Netherlands.

Tronies were made and used not only by the master painter but also by apprentices. The copying of character heads, either drawn or painted, formed an important part of an artist's training in the sixteenth and seventeenth centuries (Van Hout 2012:35). Head studies were especially useful to artists who ran a workshop with the help of studio assistants. They had a purely utilitarian function ${ }^{23}$ and the main advantage of using them was to save time and, hence, money (Van Hout 2012:35). In Flanders it was customary to execute such character studies on panel (Van Hout 2012:36). This hardy support made them more resistant to damage incurred by frequent handling in the studio.

Head studies were carefully kept in the artist's workshop for continuous use over many years. However, although Rubens appears to have kept them - along with other study materials such as drawings and oil sketches - locked up in his cantoor (office), the tronies made in his studio were also collected by other artists who collaborated with him. For example, the landscape painter Jan Wildens owned eight head studies by Rubens and another 17 by the hand of Van Dyck, while Erasmus Quellinus possessed 20 tronies painted by Rubens and eight by Van Dyck (Van Hout 2012:37-38, 41). These facts not only demonstrate the frequency of the production of such head studies, but also their distribution for use by artists other than their original makers. It also allows the deduction that the appearance of a particular tronie in a particular painting is an unreliable criterion in matters of attribution.

\section{Rubens in Italy}

As an artist, Rubens had an unusual interest in the imagery of dark-skinned people. In my 


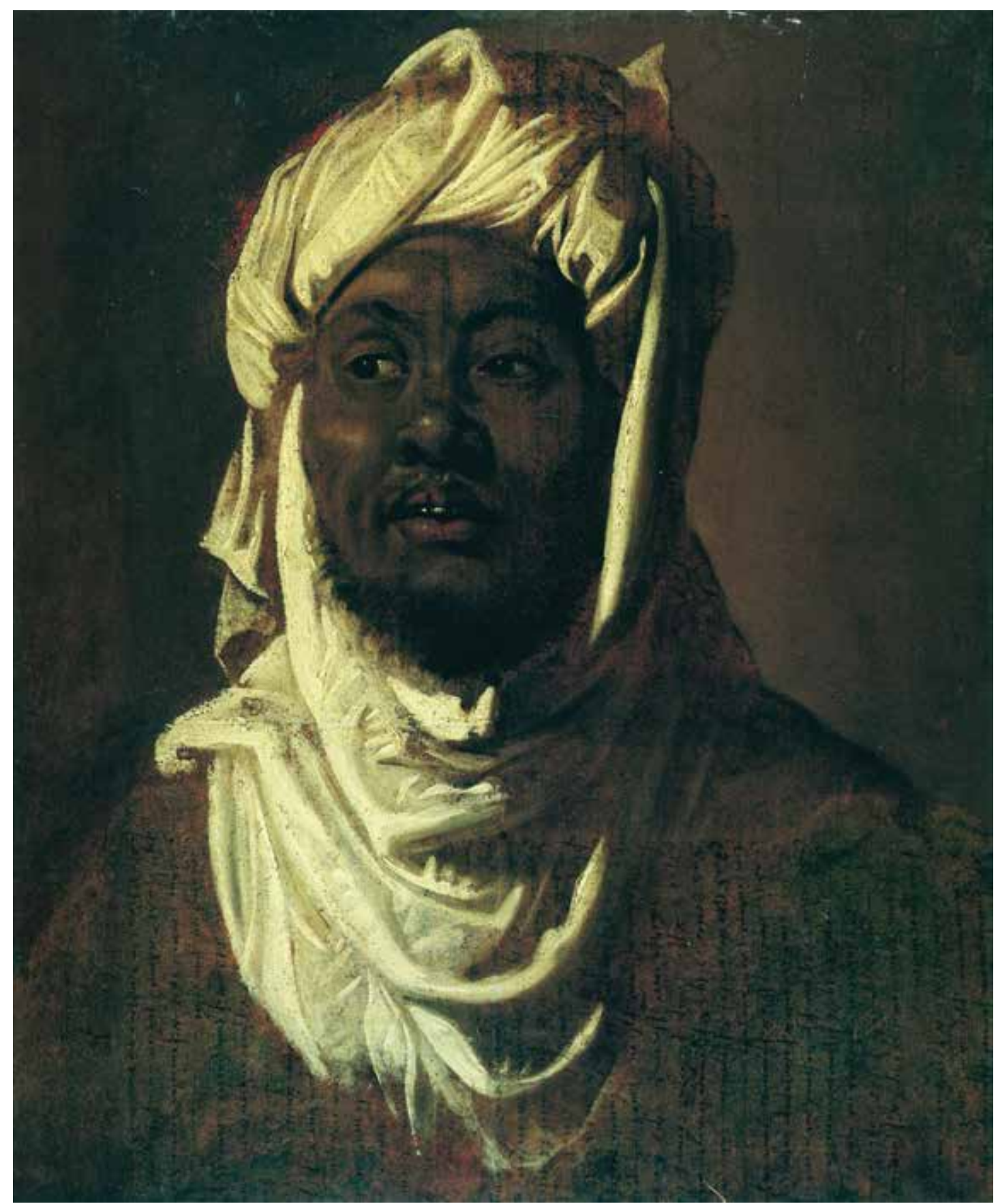

2 Peter Paul Rubens, Study of an African Man with a Turban (1608). Oil on paper laid down on wood, 54 x $39.3 \mathrm{~cm}$ (paper), 47.3 (wood). Formerly Collection Christopher Norris, London; present location unknown.

view this interest was fuelled by his personal experiences in Italy (1600-1608). It was from the Italian artists that he observed the practice of making head studies (Wheelock 2005:186). Moreover, he would have encountered more Africans in Italy than in Antwerp. The first surviving black tronie made by Rubens is the
Study of an African Man with a Turban ${ }^{24}$ (2) which was created in Rome. ${ }^{25}$ The oil sketch on paper is of a bearded African man wearing a turban. Actually, his entire face is framed by a white cloth as the turban extends under the chin and is wrapped around the neck to cover the upper chest. Although the man faces 
the viewer frontally, his eyes are turned to the left and his lips are slightly parted, showing a glimpse of his front teeth. This head study is a palimpsest as it is executed over an older text at right angles to the image on a large sheet originally used for accounts (Vander Auwera 2008a:185). The choice of medium, namely paper instead of panel, betrays an origin in Italy. ${ }^{26}$ This is further corroborated by the fact that the model was not studied by any other Flemish master in Antwerp.

Vander Auwera (2008a:185) briefly mentions the possibility of a connection between Rubens' sketch and the visit paid to the papal court by the black ambassador from the king of Kongo - a suggestion worth pursuing. Kaplan (2010:160) reports that Antonio Manuel, also known in Europe as the Marquis of Ne Vunda, was sent by his uncle King Alvaro II of Kongo as an envoy to the Pope in 1604 . However, he only reached Rome in 1608 where he was eagerly awaited by Pope Paul V. The Pope arranged an elaborate protocol for the entrance of Ne Vunda and his retinue during the first week of 1608 , including a procession on 6 January, the Feast of the Epiphany. Unfortunately the long journey had taken its toll and Ne Vunda died a few days after his arrival in Rome on the evening of 5 January 1608. Hence the 6 January procession became a funerary one, described by Kaplan as quite splendid:

Ne Vunda's body, accompanied by several members of his entourage, was taken to the great early Christian basilica of Santa Maria Maggiore rather as if his cadaver were one of the Three Kings coming to adore Mary and her Child. (Kaplan 2010:160)

By all accounts this visit created quite a stir and it is clear from the Pope's arrangements that he wanted to use this opportunity to propagate the power of the Church. By parading the Africans in the streets of Rome it could be demonstrated how far the arms of the Roman Catholic Church reached, embracing the black peoples of Africa in its fold. At that

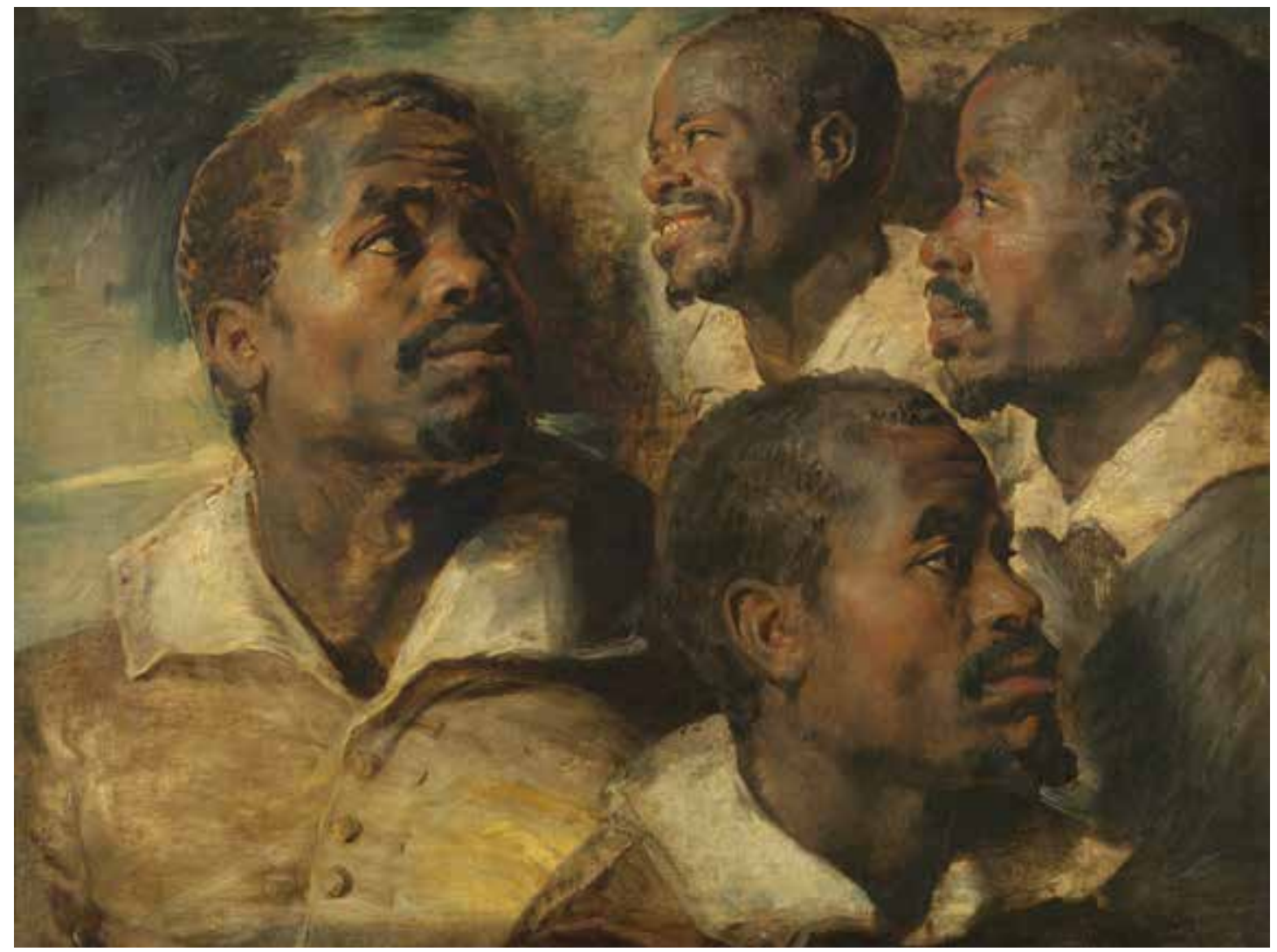

3 Peter Paul Rubens, Four Studies of the Head of a Black Man (ca. 1615). Oil on wood transposed onto canvas, $51 \times 66 \mathrm{~cm}$. Brussels, Royal Museum of Fine Arts of Belgium, inv. 3176. (c) [Koninklijke Musea voor Schone Kunsten van België, Brussel. Photograph by J. Geleyns / Ro scan] 


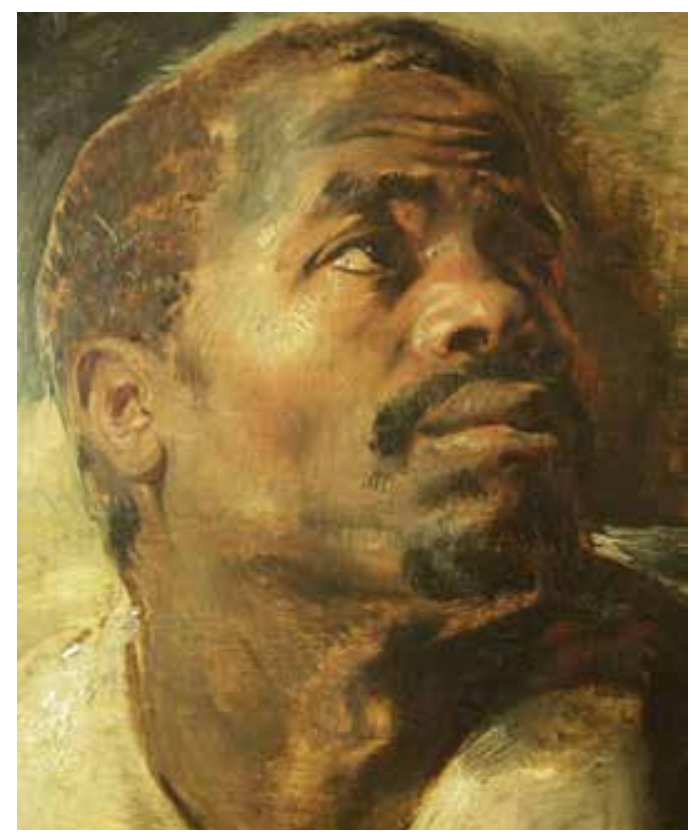

4 Detail of Fig 3: View 1.

time Rubens was in Rome working for the Oratorian Fathers on the altarpiece for the Chiesa Nuova, called S. Maria in Vallicella (Jaffé 1977:89-91), so it is entirely possible that Rubens was among the spectators witnessing the procession.

To suggest that Rubens was in Rome at the time of Ne Vunda's death does not, however, imply that he quickly sketched the head of one of the African men slowly walking past him in the funerary procession. The detailed execution of the head suggests that Rubens must have asked the African man to pose for him, even if the sitting was not planned (which would explain the use of an old piece of paper). ${ }^{27}$ According to McGrath (2008a:97), the man in question is a Moorish dignitary. If so, Rubens may have made his acquaintance at the house of a friend or employer. What is more important about the scenario suggested above, however, is that the event in Rome sensitised the artist towards the African subject. If such respect was shown by the Pope to the African ambassador, one can understand why the devoutly Catholic artist usually represented his black figures with dignity and sympathy, as in this case. ${ }^{28}$ This Italian experience would have a lasting effect on Rubens when he returned to Antwerp.

\section{Rubens in his Antwerp studio}

Rubens often made head studies in the late 1610 s for use in his workshop (Wheelock

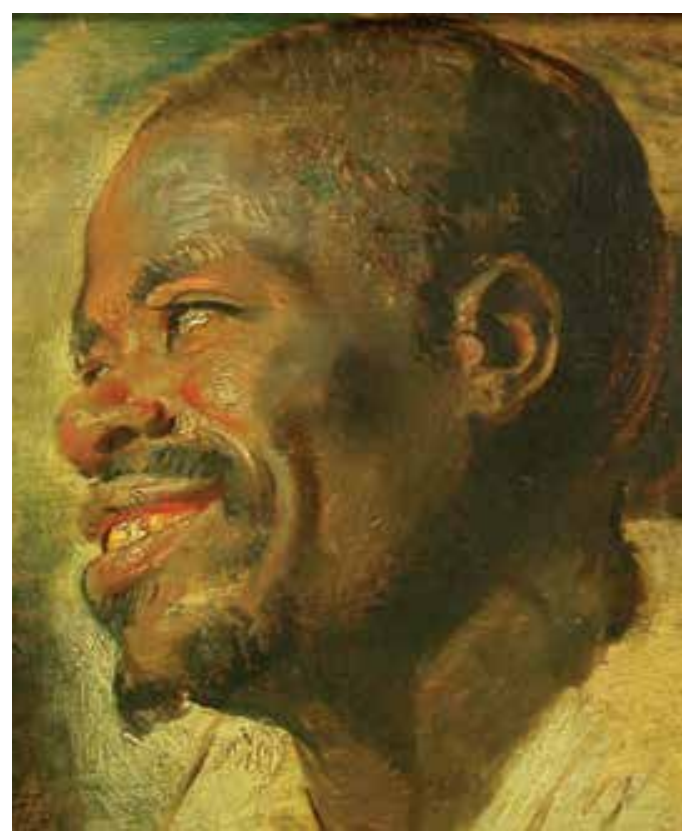

5 Detail of Fig 3: View 2.

2005:186). With Africans being a not uncommon sight in Antwerp, it would have been relatively easy for the artist to ask a black servant to pose as a model. One such study was made around 1615, when he invited an African model to his studio to pose for his Four Studies of the Head of a Black Man (3). ${ }^{29}$ This study of an African head, seen from four different angles, has been hailed as one of the most evocative and lifelike renditions of a black subject. Whereas the attribution of the work either to Van Dyck or Rubens - has been the subject of critical dispute (D'Hulst 1954; Held 1982:149-155), everyone agrees that it is the same individual shown four times. The model is an adult African with closely cropped hair, a 'pulled down moustache' (Held 1980:607) and a small goatee. On the left (View 1) (4) the man occupies half of the picture plane. His body is positioned frontally while his head is turned to the right and tilted upwards. He wears a white shirt with a wide collar underneath a buttoned, dull yellow jacket. We see him again (View 2) (5) higher up and further back - hence smaller in size - with only part of the white collar visible ${ }^{30}$ but now his face, which is creased into a broad smile, is turned to the left. In both cases the eyes look upwards.

On the right-hand side of the composition, at the bottom and closest to the viewer, he is shown in three-quarter view (View 3) (6) 


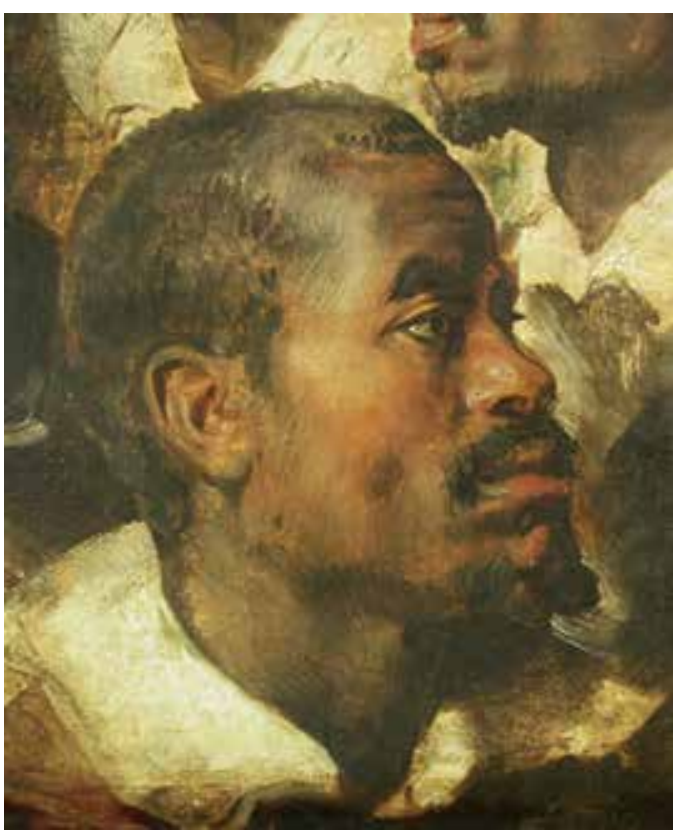

6 Detail of Fig 3: View 3

staring straight to the right, his shoulders at an angle with the picture plane. As far as his outfit is concerned, all that can be seen is the collar of a white shirt and the top of a brown jacket. ${ }^{31}$ Higher up on the extreme right the man is posed in full profile (View 4) (7), looking straight ahead to the left. ${ }^{32}$ The collar of his white shirt is folded over a greyish blue jacket. According to Held (1982:151), Views 1 and 3 were painted first and since they fill a major part of the available surface, Views 2 and 4 had to be squeezed into the remaining space.

Rubens' interest in painting black people was not only driven by his admiration for the robust physique of dark-skinned people, as discussed above. As stated by Vander Auwera (2008a:185), another incentive was the fact that the rendering of dark skin presented artists with a new technical challenge. In Four Studies of the Head of a Black Man the artist tackled the challenge with such inventiveness and virtuosity that an attribution to Rubens seems entirely justified. The thin paint application, subtle use of colours and attention to detail resulted in a remarkable realism. In order to paint the dark skin in all its gradations, the artist's palette ranged 'from light beige to grey-brown, greenish-brown and red-brown, red, white and a deep dark brown' (Kolfin 2008:78).

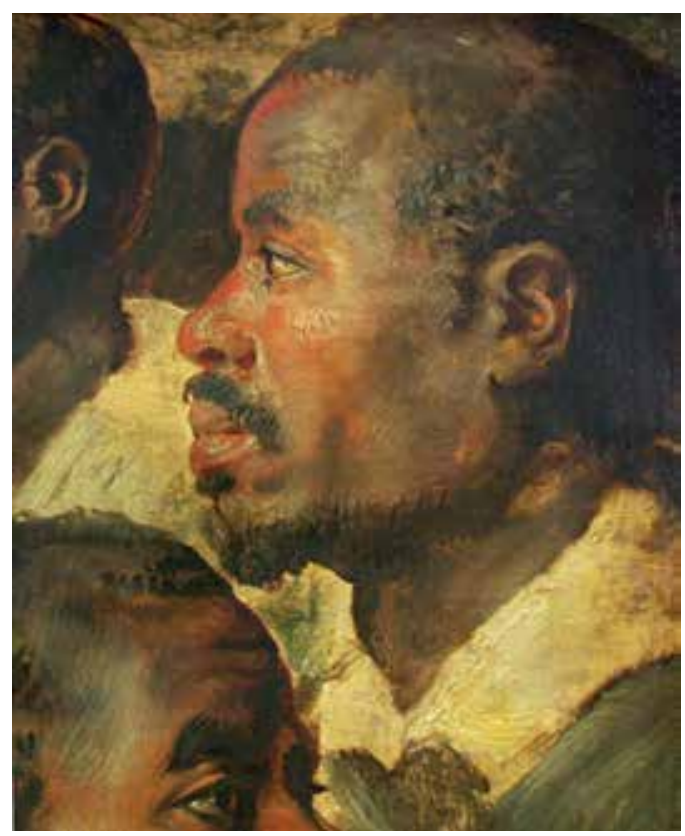

7 Detail of Fig 3: View 4.

Around 1620, Rubens made another study of a Head of a Moor (8), now in Glen Falls. ${ }^{33}$ It shows a single black man's bust, his head turned to the left and seen in threequarter view. Wearing a simple white shirt he bows his head and lowers his eyes in a moving expression of sadness. It was Julius Held (1982:153) who suggested that the model is the same man who posed for the Brussels picture. In this case the serious young man, aged by about five years, seems to have been captured by the artist in an unguarded moment. Seeing that Rubens used the same model within a time span of five years it is clear that the African was living in Antwerp, probably as a servant in a wealthy family (Held 1980:612).

\section{Studio assistants and collaborators: Anthony van Dyck and Jan I Brueghel}

Interestingly, a copy was made after the Rubens painting in Brussels, probably in the artist's own studio. The Four Studies of a Male $\mathrm{Head}^{34}(9)$ is kept in the Getty Museum in Malibu and represents the same four views of the African head as in the Brussels painting. However, by using a longer board the artist could spread out the heads more evenly and present them in a more or less horizontal row. From the left the heads of the Brussels study 


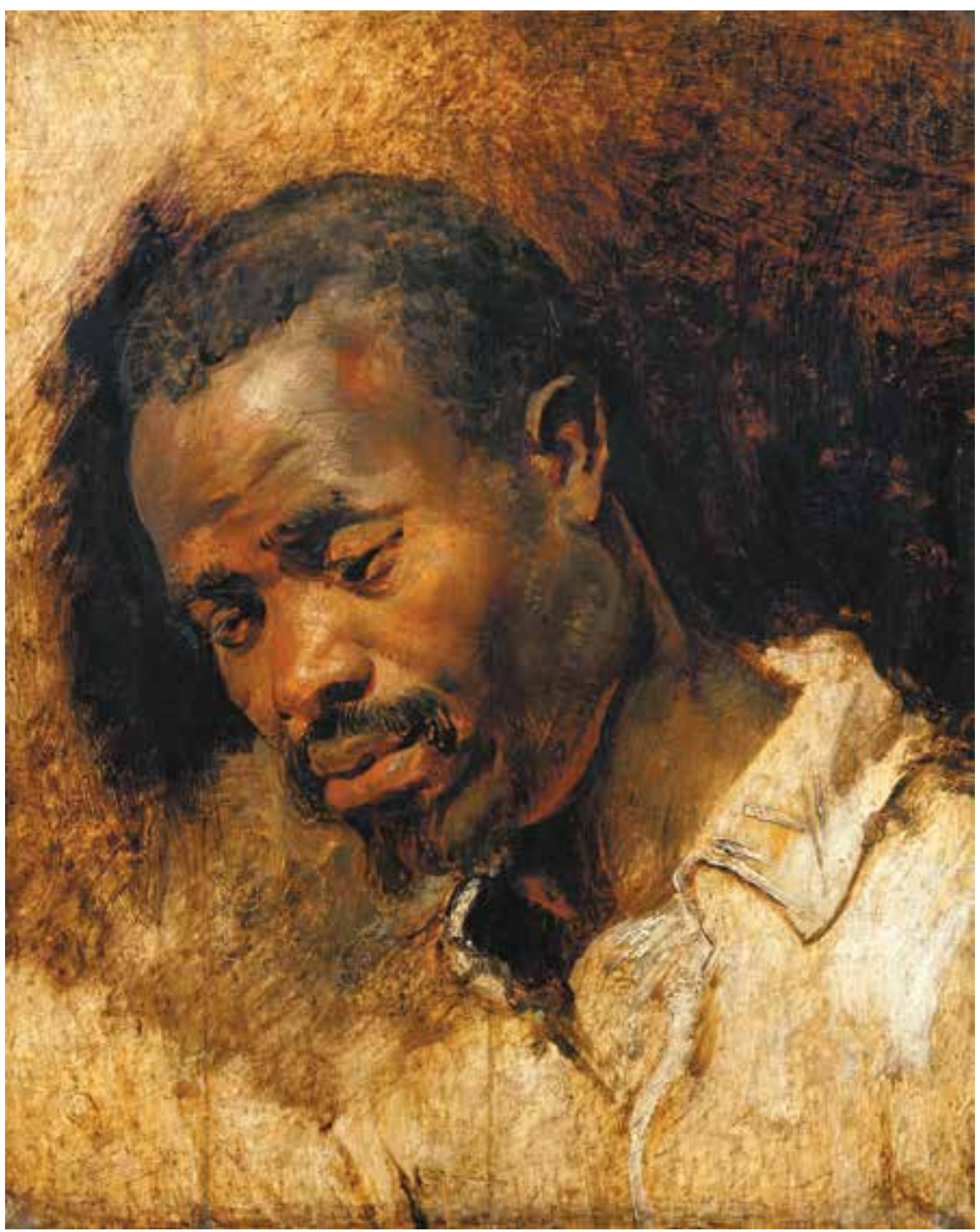

8 Peter Paul Rubens, Head of a Moor (ca. 1620). Oil on panel, 45.7 x $36.8 \mathrm{~cm}$. Glen Falls, New York, The Hyde Collection, Bequest of Charlotte Pruyn Hyde, inv. 1971.40. Photograph by Joseph Levy.

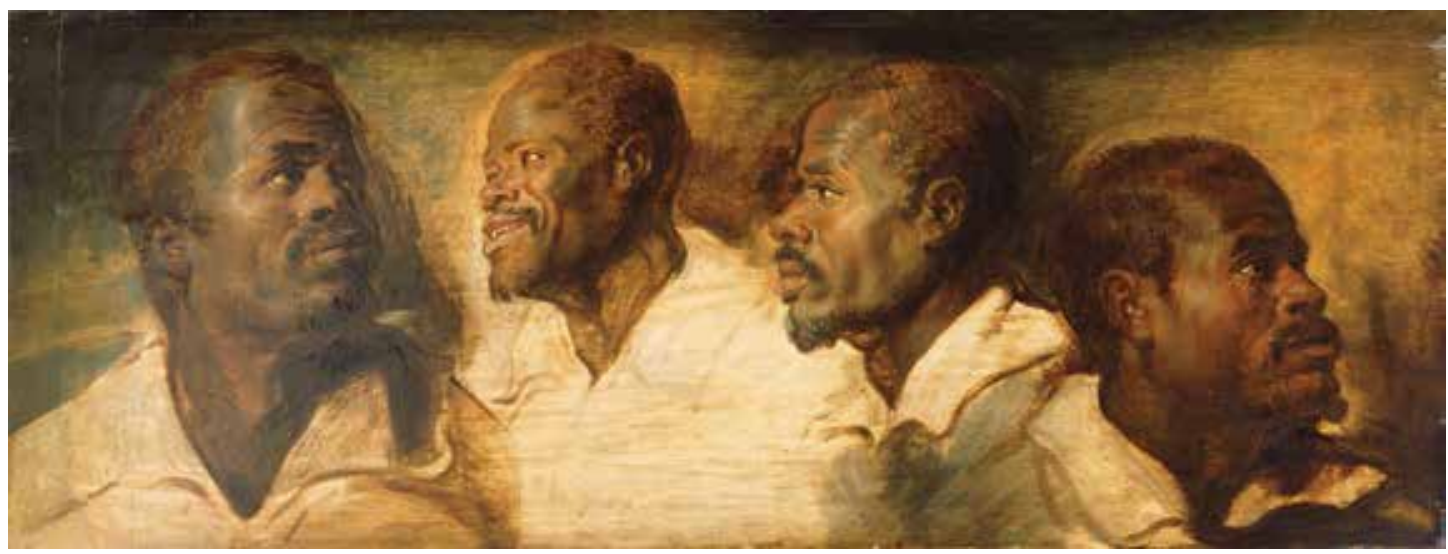

9 Workshop of Rubens, Four Studies of a Male Head (ca. 1615). Oil on wood, $25.4 \times 64.8 \mathrm{~cm}$. Los Angeles, J. Paul Getty Museum, inv. 71.PB.39. 
are arranged in the following order: Views 1 , 2, 4 and 3. Since View 3 has now been moved to the extreme right in front of View 4, the two profiles of this man appear back to back. A notable change is the fact that the model in Views 1 and 2 only wears a white shirt without a jacket. In Views 3 and 4 the sitter is dressed in the same shirt and greyish blue jacket worn by the man in View 4 in the Brussels study. ${ }^{35}$

Held (1982:150-151) argues that the Malibu study is a copy after the Brussels painting because, even though the longer panel provides sufficient space to depict the four heads in equal size, the head of the laughing man (View 2) is still smaller than the one in near profile (View 1). Yet the size of the model in View 2 is entirely justified in this painting: he had to be placed further back - hence reduced in scale - in order to fully catch the light streaming in from the left. The intensity of the light diminishes gradually towards the right of the painting. So whereas the heads themselves are indeed exact copies after the Brussels heads, the artist has made such significant and well-considered changes that they betray firsthand observation of the model. Perhaps the artist was present during the modelling session when Rubens made his (Brussels) study. This brings us to the issue of attribution.

As in the case of the Brussels study, the authorship of the Malibu painting has been hotly debated, swinging between an attribution to Rubens, then Van Dyck and even Jacob Jordaens (Held 1982:150). Held (1982:151) maintains that the Malibu panel was painted by 'an artist of greatly limited imagination; where his model failed to give him any guidance, he was unable to improvise anything on his own'. He concludes by stating that the 'Getty panel is not only a copy of the Brussels sketch but a copy by a less than original painter'. ${ }^{36}$ If we accept that the copy was executed in Rubens' workshop, it may have been made by a pupil or apprentice who was expected to follow the master's example in copying the original sketch - this would explain the perceived lack of imagination. The fact that he actually deviated from the master's design may suggest that the artist was more than a pupil, that is, an assistant working in Rubens' studio. If this assistant was present at the modelling session, he probably made the copy soon after Rubens had finished his study.

The assistant in question may well have been the sixteen-year-old Anthony van Dyck, whose portrait ${ }^{37}$ Rubens painted in 1615 , indicating a close relationship between Rubens and Van Dyck at that stage (Van der Stighelen 1994:29). Even though Van Dyck was never apprenticed to Rubens, ${ }^{38}$ the latter employed him on several occasions between 1615 and 1620 to assist with the execution of large commissions (Held 1994:70-71; Van der Stighelen 1994:29). As a regular visitor to Rubens' studio, Van Dyck must have witnessed the rare posing of a black model and jumped at the opportunity to learn from Rubens, while giving the composition his own interpretation. Rubens may even have instructed Van Dyck to paint a copy for use in his workshop. Barnes (in Barnes et al. 2004:17) warns that 'the attribution of these Rubensian heads is difficult and relies solely on how we assess style and facture'. Perhaps the different inconsistencies enumerated by Held (1982:151-152) as proof of the 'unquestionably inferior quality' of the Getty panel ${ }^{39}$ should rather be attributed to the young artist's inexperience and attempts at learning to paint black faces.

The fact that Van Dyck did not use these specific head studies in his later paintings ${ }^{40}$ has been used as an argument to support the view that he did not execute the studies (Held 1982b:153). Strictly speaking, the tronies - being painted by an assistant in Rubens' workshop - were the property of Rubens. ${ }^{41}$ As a matter of fact, Rubens kept his visual archive of head studies until his death in 1640. In the inventory detailing the artist's possessions there is mention of a number of heads, as many by Rubens as by Van Dyck (Van Hout (2012:36-37). ${ }^{42}$ Furthermore, the suggestion that Van Dyck studied the African model first hand gains support from the existence of a sheet of Eleven Study Heads ${ }^{43}$ drawn with pen and brown ink. In this particular drawing or 'model-sheet' which consists of a collection of many different heads, ${ }^{44}$ the smiling black man (View 2) appears in the bottom right corner. Held (1980:599) concedes that 'it is perfectly possible that heads recorded by Van Dyck on the Chatsworth drawing were done from some of his own studies painted in Rubens' studio'.

This same head features in the Frankfurt painting of a Head of a Black Man (ca. 1640-1650) $)^{45}(10)$, executed by a follower of Van Dyck and described as a copy after the 'happy' head (View 2) in the Brussels painting (Tieze 2009:182). It shows the bust of a smiling black man in three-quarter view 


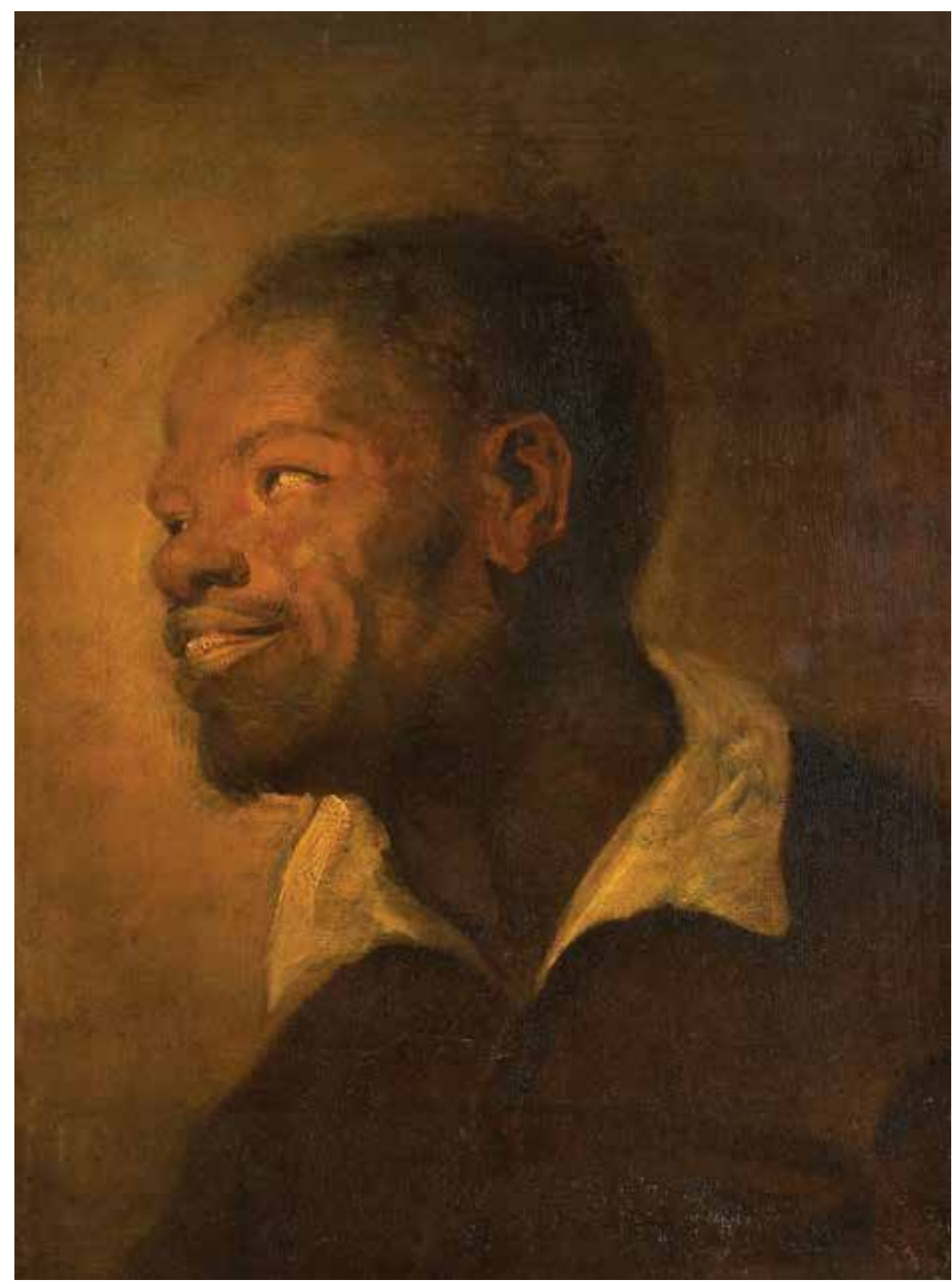

10 Follower of Van Dyck, Head of a Black Man (ca. 1640-50). Oil on wood, 42.5 x $32.3 \mathrm{~cm}$. Frankfurt am Main, Städel Museum, inv. 889

looking upwards to the left. He wears a dark brown, buttoned jacket (very similar to View 1 in the Brussels picture) and the collar of his white shirt is neatly folded over it. He has a thin moustache and goatee. According to Tieze (2009:186), the work was made by a follower of Van Dyck, ${ }^{46}$ which may imply that Van Dyck kept another copy of his black tronies in his own studio. ${ }^{47}$

Undoubtedly Rubens set an important example by executing studies of black people.
As mentioned above, the tronies made for use in the studio by Rubens himself and his assistants were also accessible to other painters who visited the workshop as collaborators. Jan I Brueghel was one such master painter with whom Rubens collaborated in 1615 on the painting of Nature Adorned. ${ }^{48}$ Given these facts it is tempting to assume that Breughel also tried his hand at sketching the foreign model. A small panel painting representing Studies of Heads (11) has been attributed to him. ${ }^{49}$ Apart 


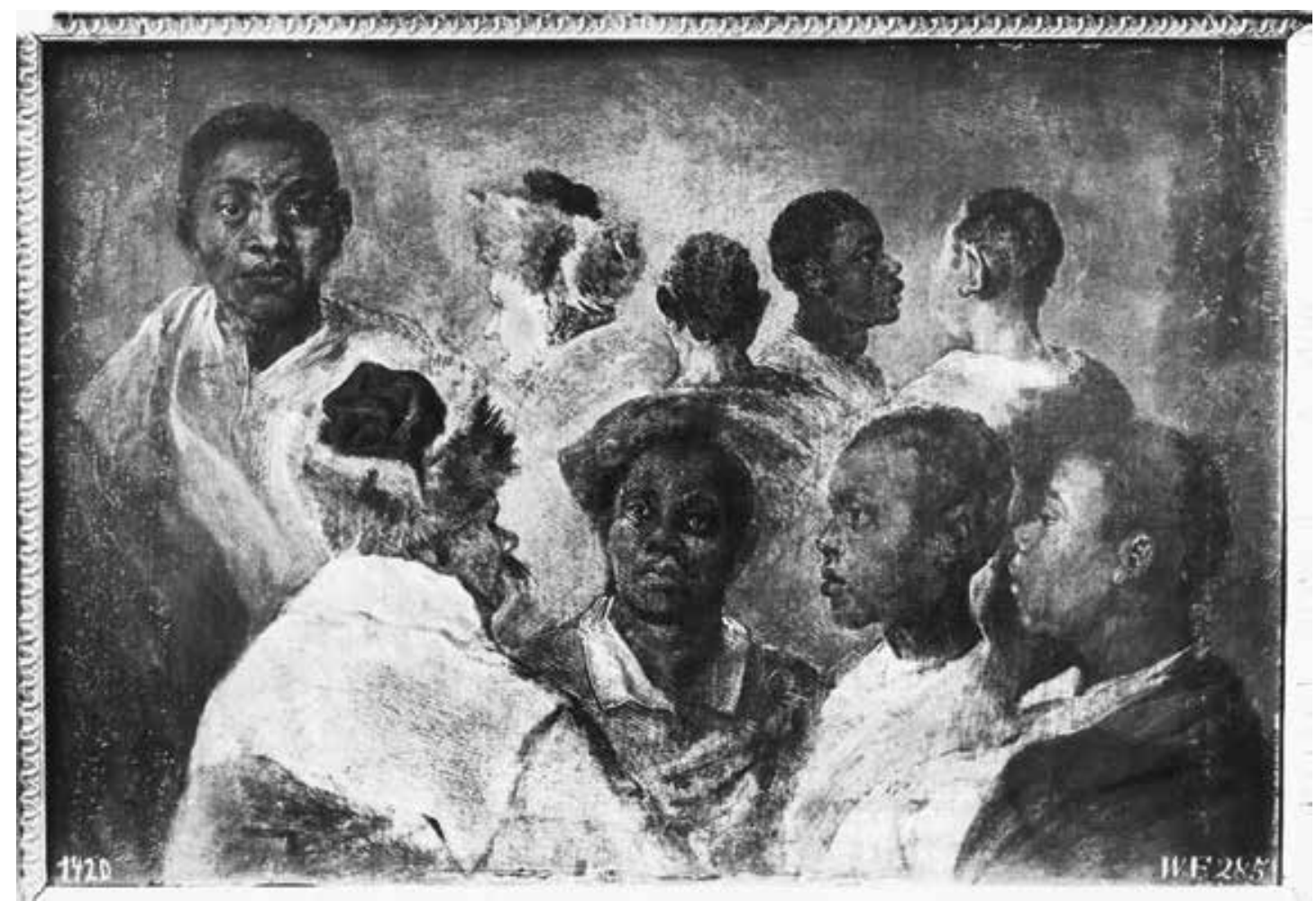

11 Jan I Brueghel, Studies of Heads. Oil on wood, 26.3 x $32.2 \mathrm{~cm}$. Rohrau, Graf Harrach'sche Familiensammlung, inv. WF 285.

from seven black heads there are also two views of a white man wearing a fur hat. The heads are painted rather crudely (Brueghel was far better at flower painting), making it difficult to assess the appearance of the individual figures. However, none of the heads betray even a superficial resemblance to Rubens' black man. It is also hard to tell how many models the artist portrayed. ${ }^{50}$ For instance, the second head from the right in the bottom row appears to be that of a young black female who features as a servant in his painting of the Allegory of Winter (1616)..$^{51}$

This finding can be interpreted in different ways. If the painting is a copy after a lost sketch by Rubens - as claimed by Held (1980:600) - it could indicate the presence of an African girl or woman (or both) in Rubens' studio. It was indeed in 1615 that Rubens created his paintings of Venus of the Night ${ }^{52}$ and The Four Rivers, ${ }^{53}$ both of which feature a black woman. It thus makes sense to assume that Rubens also invited black females to pose for him even though such tronies did not survive. If the study is not a copy after Rubens, Brueghel probably sketched his own versions of black tronies after African models - male and female - which he had an opportunity to study in Rubens' workshop. Given the fact that he usually worked together with a figure painter to provide the staffage in his paintings, it is likely that he made the African head studies to serve as example for his collaborator and to share the novel practice of painting black figures.

\section{Other Flemish artists: Jacob Jordaens and Gaspar de Crayer}

Another painter from Rubens' circle was Jacob Jordaens, whose Study of a Black Man's Head $^{54}$ (12) is, in Kolfin's (2008:78) opinion, an oil sketch of the same man depicted by Rubens. Here we have two views of a black man looking to the left into the light source. On the left he is turned in profile with his eyebrows raised and part of a yellow collar visible. On the right he is depicted in threequarter view with his eyes slightly lowered, a smile on his face and a white cloth covering his hair. Jordaens developed his own particular technique to reproduce black skin. He created a much darker complexion than Rubens by using 


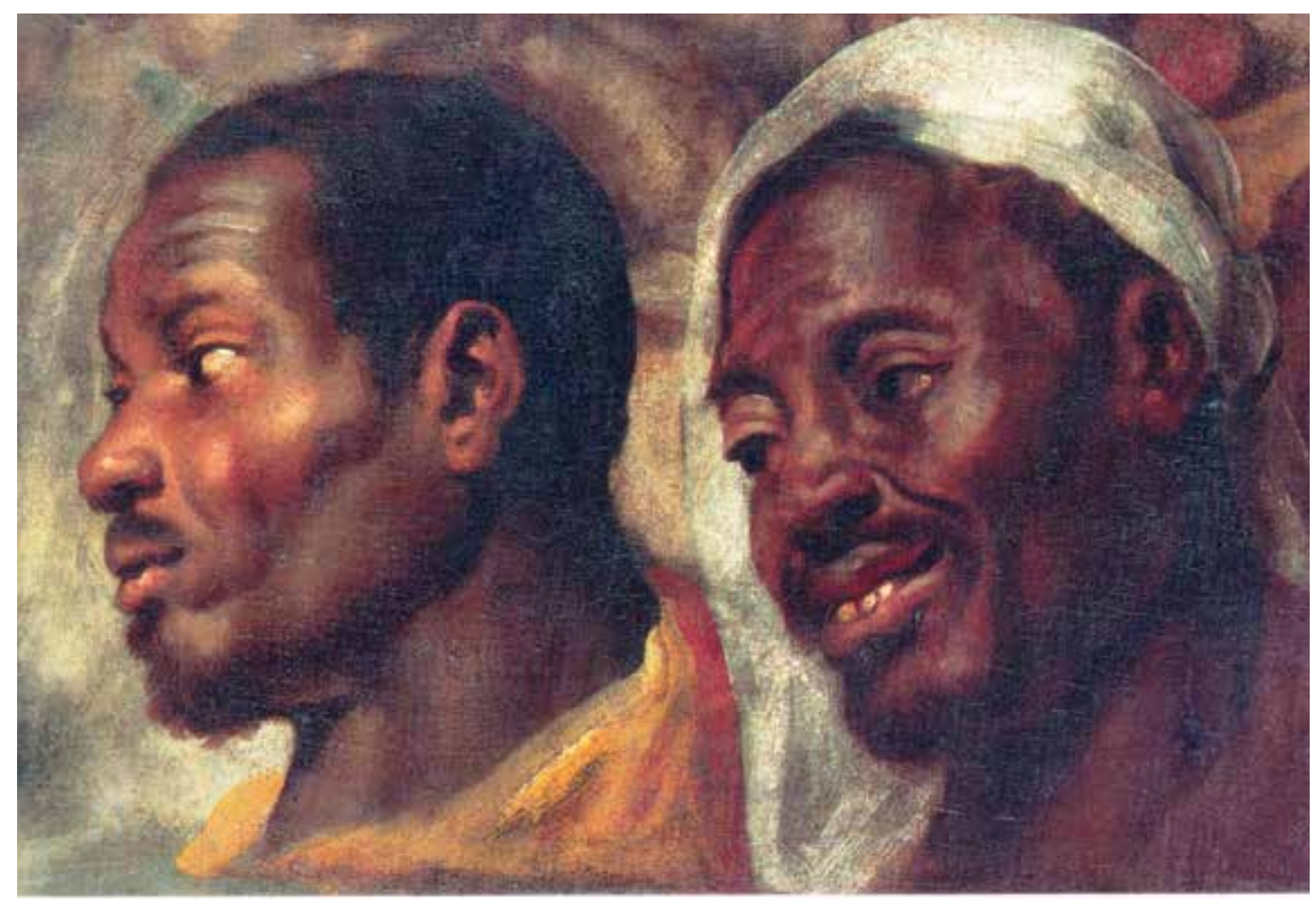

12 Jacob Jordaens, Study of a Black Man's Head (ca. 1620). Medium and size unknown. Formerly New York, Estate of Jacob Goldschmidt; present location unknown.

deeper tones of brown with white highlights. The skin is so dark that the artist applied white brushstrokes in the background - and a white headdress extending along the right-hand side of the smiling face - in order to make the faces stand out.

Jordaens' study is believed to have been created around 1620. The lack of a proper model before that time is evidenced in his earliest work. First, in The Rape of Europa, ${ }^{55}$ made around 1615, the head of an African figure can be discerned in the dark triangle formed between the woman on the extreme right and the naked woman kneeling before her. The 'black' woman has no obvious negroid features, indicating that the artist simply used a white model whose face was blackened. Then around 1617, Jordaens included the head of a dark-skinned satyr in the Allegory of Fruitfulness of Munich. ${ }^{56}$ In this instance he relied on the example of Rubens and simply copied the motif from the latter's Nature Adorned (ca. 1615). ${ }^{57}$ It was only in the 1620s that Jordaens made several oil sketches of individuals posing for him in his studio. According to D'Hulst (1982:90), the appearance of such tronies is related to the development of his workshop.

Did Jordaens sketch the same model represented in Rubens' study of ca. 1620?58 In my view the artist used another African man to pose for him. This would, in the first place, be in line with the rather strict rules governing the use of tronies (as already seen in the case of Van Dyck). While Rubens shared his models and his studies thereof with assistants and collaborators, he may have been less generous towards other master painters running their own studios. It has been observed, for example, that Jordaens' head study of an old woman, once he had included it in a painting made on request of Rubens, became the property of Rubens since the tronie does not reappear in Jordaens' later compositions (Van Hout 2012:41). Second, my suggestion is supported by the inclusion of his Study of a Black Man's Head in subsequent paintings. In Apollo Flaying Marsyas ${ }^{59}$ (13), created in the early 1620s, the dark-skinned satyr who occupies a central position opposite Apollo is recognisable 


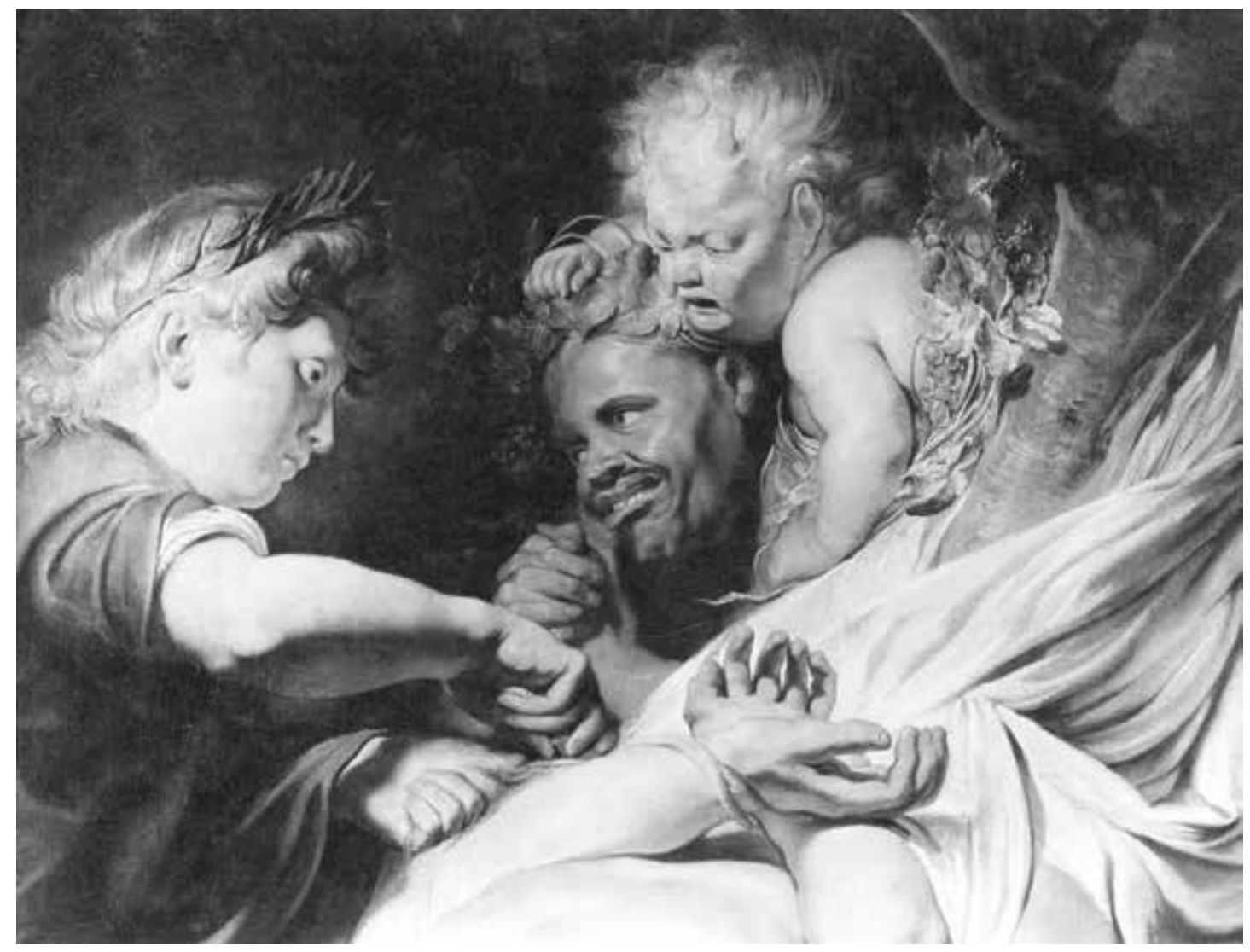

13 Jacob Jordaens, detail of Apollo Flaying Marsyas (early 1620s). Oil on canvas, 146 x $117 \mathrm{~cm}$. Antwerp, Huis Osterrieth. Photograph KIKIRPA.

as the smiling black man on the right in the study. Around 1623 Jordaens included this face again, this time looking upwards, ${ }^{60}$ in the Allegory of Fruitfulness ${ }^{61}$ and in The Apostle Peter Finding the Tribute Money in the Fish's Mouth. ${ }^{62}$ Even accounting for stylistic differences, this man bears no resemblance to Rubens' African model.

Gaspar De Crayer's Head of a Young Moor ${ }^{63}$ (14) seen in profile was made years later between 1631 and 1635. ${ }^{64}$ Set against a very dark background, he looks upwards to the left from where a bright light illuminates him. He has short curly hair, a moustache and goatee and wears a greyish beige shirt. His mouth is slightly open, revealing the upper front teeth - a feature that characterises most black tronies. The artist made use of yellow to ochre brushstrokes on the forehead, the upper eyelid and the bridge of the nose to define the impact of the light on his face. The contours of his lips are marked by a bright outline, resulting in a marvellously realistic rendition of a sympathetic face. McGrath (2008b:266) rightly dismisses
Kolfin's claim that the African is the same man used by Rubens for his Brussels study and suggests that 'the young man may even have been a member of the artist's household'. In light of the fact that De Crayer was at that time the most important painter in Brussels, with connections in court circles (Vlieghe 1994:202), that possibility is indeed viable.

Although De Crayer was definitely inspired by Rubens' artistic output (Vlieghe 1994:205), his interest in black people was triggered by Van Dyck. During the winter of 1634-1635 Van Dyck spent some time in Brussels painting portraits of nobles living near the Brussels court. Since De Crayer moved in the same circles, it is most likely that the two artists established personal contact (Vlieghe 1994:201-202). De Crayer already showed an interest in Van Dyck's work even before 1630, but according to Vlieghe (1994:202) it was Van Dyck's portrait of Henrietta of Lorraine $(1634)^{65}$ that inspired De Crayer to include the motif of the black groom in his portrait of Charles V Exhorting His Great-Grandson 


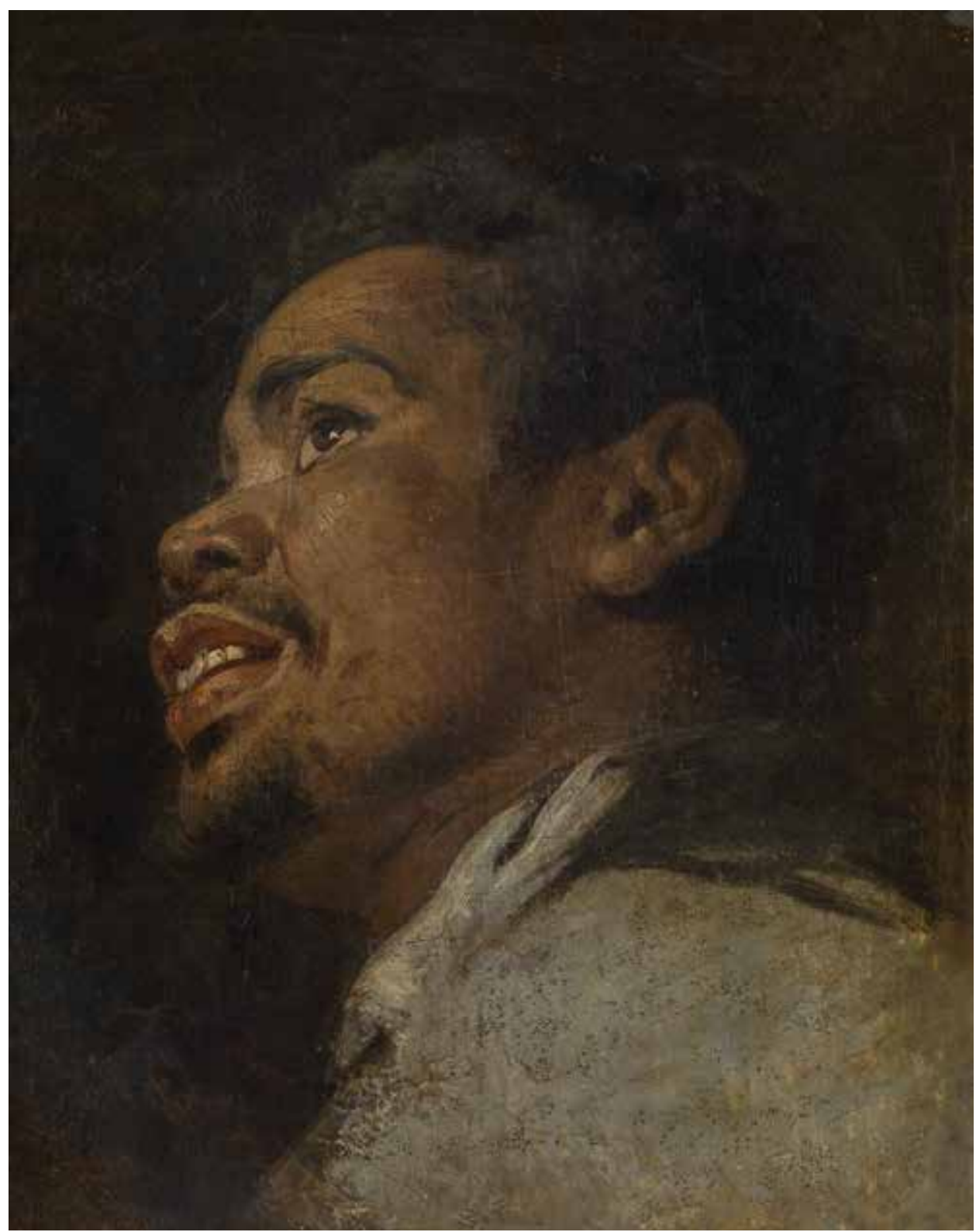

14 Gaspar de Crayer, Head of a Young Moor (ca. 1631-35). Oil on canvas, 39.5 x $32.7 \mathrm{~cm}$. Museum voor Schone Kunsten Gent (c) Lukas - Art in Flanders vzw, Photograph by Hugo Maertens.

Ferdinand to Follow His Example (1635). ${ }^{66}$ Similarly, in his painting of the Raising of the Cross (ca. 1631-35), ${ }^{67}$ which is undeniably derived from Van Dyck's version painted in 1631 for the Church of Our Lady in Kortrijk ${ }^{68}$ (Vlieghe 1994:206), De Crayer added three executioners who strain to raise the cross into an upright position. Here we see for the first time the young black man portrayed in the Head of a Young Moor featuring as one of the executioners pushing up the cross by means of a long stick.

\section{Conclusion}

Although Rubens played a leading role in establishing the study of the African figure as a studio practice, his contribution should not be overestimated. It is unrealistic to suggest that the Flemish artists all sketched the same model who posed in Rubens' studio. To assume that there was only one African man available to use as model is equally unlikely. As discussed above, black people were not an uncommon sight in Antwerp in the early 
seventeenth century. Rubens probably invited along the African man's wife, child, other family members or friends whose tronies have not survived. Unless they set out to make a copy after an existing head study - as in the case of the Getty and Frankfurt pictures artists would have been perfectly capable of finding their own respective models. When studied meticulously, the black tronies reveal different persons captured in a realistic mode. The artists showed a genuine concern with the individualised representation of their sitters, in an attempt to transform the black figure from a merely decorative motif or symbolic allusion into a convincing role player in a grander narrative. The fact that we do not always recognise these individuals has more to do with a lingering tendency to view black Africans as a racial group with common physical characteristics - a legacy of the hierarchic classifying impulses of the Enlightenment - than with the Flemish artists' actual visualisation of the Africans.

\section{Acknowledgements}

I acknowledge the assistance and advice of Arnout Balis, Elizabeth McGrath, Sheldon Sheek, Paul Taylor, Joost Vander Auwera and Hans Vlieghe. This research was made possible by a Foreign General Research Grant from the College of Human Sciences, University of South Africa. Please note, however, that any views or findings expressed in this article are my own.

\section{Notes}

1 The term 'Africans' is used to denote darkskinned people of African origin who in the distant past were called 'Moors' (Schreuder and Kolfin 2008:15). I use the terms 'African' and 'black' interchangeably to denote black people men, women and children - of African descent.

2 Peter Paul Rubens, Four Studies of the Head of a Black Man (ca. 1615). Oil on wood transposed onto canvas, $51 \times 66 \mathrm{~cm}$. Brussels, Royal Museum of Fine Arts of Belgium, inv. 3176 (Held 1980:607-609, cat. no. 442, plate 430; Kolfin 2008:78; Massing 2011:1, ill. I.1). Note that in the latter source the painting is unfortunately reproduced in reverse.

3 Albrecht Dürer, Portrait of Katherina (1521). Drawing, $20 \times 14 \mathrm{~cm}$. Florence, Gabinetto del Disegni e Stampe degli Uffizi. (Debrunner 1979:61; Haarnack and Hondius 2008:9091, fig. 32; Kolfin 2008:71-72; Massing 2011:233). Katherina was the twenty-year-old African servant of João Brandão, the King of
Portugal's representative in charge of the spice monopoly in Antwerp. Dürer was staying with the Brandão family at the time and recorded the event in his diary (Massing 2011:233).

4 Jan Mostaert, Portrait of an African Man (1520-25). Oil on panel, $30.8 \times 21.2 \mathrm{~cm}$. Rijksmuseum, Amsterdam, inv. SK-A-4986. (Schreuder 2008:268-269, cat. 72). It has been suggested that the sitter is Christophle le More, a courtier of Emperor Charles V, but this identification remains uncertain (Massing 2011:217; Schreuder 2008:269). According to Schreuder (2008:269), Mostaert may have received the commission at the court of Margaret of Austria in Mechelen when he was in Flanders around 1521. The gold insignia on the man's Flemish cap refers to the shrine of the Black Virgin of Halle near Brussels, a celebrated place of pilgrimage (Massing 2011:217).

5 Jordan (2005:157) claims that by 1552 black Africans formed about ten per cent of the total population of Lisbon. By 1620, 10470 slaves were counted in Lisbon alone (Debrunner 1979:38).

6 See also Haarnack and Hondius (2008:90-91).

7 See also Kolfin (2008:71) and Massing (2011:233, 236).

8 The two taxes concerned were the tax of the $10^{\text {th }}$ penny on the sale of movable goods and the tax of the $20^{\text {th }}$ penny on real estate, both to be paid by the seller. Denuce (1937:82) is of the opinion that it was the Duke of Alva's taxes, not the religious issue, which caused the revolt.

9 While Goris (1940:119-120) does not specify the first name of Duarte, he probably refers to Diego Duarte (before 1616-1691), son of Gaspar Duarte whose business passed to Diego. De Clippel (2006:24) describes Diego Duarte as a Portuguese Jew who was a fabulously wealthy jeweller and banker.

10 'Nu ziet men in plaats van de kooplieden en handelaars, niets dan Spanjaarden door al de straten "braveren"' (quoted in Goris 1940:66).

11 Attributed to Hieronymus II Francken, The Cabinet of the Art Lover (1621). Panel, 94 x $124.7 \mathrm{~cm}$. Brussels, Royal Museum of Fine Arts of Belgium, inv. 2628 (www.fine-arts-museum/ be).

12 Sebastiaen Vrancx, Winter Pastime on the Scheldt at the Kranenhoofd in Antwerp (1622). Panel, $58.5 \times 113 \mathrm{~cm}$. Monogrammed SV and dated 1622. Amsterdam, Rijksmuseum (Vander Auwera 1981:140). I thank Joost vander Auwera for bringing this work to my attention.

13 The theme of the Baptism of the Eunich was, however, only popular in the northern Netherlands, especially between 1620 and 1650 when the united provinces developed their overseas interests (Massing 2011:284-294). In Catholic countries the preference was for 
pictures of the Adoration of the Magi to celebrate the universality of Christ's message (Massing 2011:311).

14 See, for example, Peter Paul Rubens, Adoration of the Magi (1609, reworked 1628-29). Oil on canvas, 355.5 x $493 \mathrm{~cm}$. Prado, Madrid, inv. P01638.

15 For a discussion of the anthropology of the African in the sixteenth and seventeenth centuries, read Massing's conclusion (2011:395-399).

16 With regard to the question to what extent visual depictions of black people imply critical awareness of their status in a white society, Erickson (1993:507) states that 'a fully conscious critical perspective' was not yet formed.

17 See also Kolfin (2010:275) on Rembrandt's interest in Africans.

18 Classical writers such as Pliny attributed the black skin of Africans to their proximity to the sun. In the Middle Ages blackness was seen to be caused by the curse of Ham, son of Noah, who was punished for mocking Noah's nakedness. Ham's descendants were identified with Africans (Massing 2011:396-397).

19 Rubens' Théorie de la figure humaine (quoted by Vander Auwera 2008b): 'Des trois espèces d'hommes forts et robustes les Ethiopiens, les Africains et les Turcs tiennent en quelque manière des proportions de cette statue: non qu'ils avent la même force, mais leurs membres sont à peu près semblables, à ceux de cet Hercule. Ils ont, par exemple, la tête ronde, les cheveux crépus comme les poils du taureau, le col court et plein de muscles, les épaules larges, etc.'

20 The power relations he refers to are those between the Europeans as the white masters and the Africans as the black servants. While I agree that there must have been a 'fixed social distance' between them (Erickson 1993:6), the presence of black people in Flanders was certainly not strong enough to elicit any anxiety about power imbalance.

21 See the examples referred to above by Hieronymus II Francken (note 11) and Sebastiaen Vrancx (note 12).

22 Flemish School, Two Black Heads. Oil on canvas, $16.5 \times 20.3 \mathrm{~cm}$. Formerly Paris, Collection Lady Mendl (Elsie de Wolfe); present location unknown. While the painting has been attributed first to Rubens and later to Van Dyck its authorship remains uncertain.

23 It was only later that such tronies became recognised by the art market as a separate category of art in its own right (Van Hout 2012:35).

24 Peter Paul Rubens, Study of an African Man with a Turban (1608). Oil on paper laid down on panel, 54 x $39.3 \mathrm{~cm}$ (paper), 47.3 (wood). Formerly Collection Christopher Norris, London; present location unknown (Held 1980:599600, cat. no. 433, plate 420; Vander Auwera 2008:185, cat. no. 16).

25 The suggestion that Rubens made the oil sketch during his stay in Italy is maintained by Vander Auwera (2008a:185), McGrath (2006:97-98) and Massing (2011:279). Van Hout (2012:43) mentions another black head study described as 'a black tronie in profile painted by Rubens in Italy' which was in the possession of Alexander Voet in 1678.

26 Whereas it was customary in Flanders to execute such character studies on panel, the medium of choice in the southern countries was paper. This leads Van Hout (2012:36) to assert that Rubens made his first tronies on paper.

27 See also McGrath (2008a:97-98, note 29).

28 See also Vander Auwera (2008a:185).

29 See note 2.

30 A white patch has been added in the background between the collar and the man's mouth in order to make his chin stand out more prominently.

31 Although Massing (2011:1), along with Held (1980:607), maintains that the man is depicted four times 'with the same buttoned jacket', these buttons can only be discerned in View 1 .

32 Although he appears to have a beard covering the jawbone, the dark scratches may have been applied to outline the jaw more sharply against the neck.

33 Peter Paul Rubens, Head of a Moor (ca. 1620). Oil on panel, 45.7 x $36.8 \mathrm{~cm}$. Glen Falls, New York, the Hyde Collection, Bequest of Charlotte Pruyn Hyde, inv. 1971.40 (Held 1980:612, cat. no. 447, plate 435. )

34 Workshop of Peter Paul Rubens, Four Studies of a Male Head (ca. 1615). Oil on panel, 25.4 x $67.9 \mathrm{~cm}$. Formerly Knowsley Hall, Collection Earl of Derby; Los Angeles, the J. Paul Getty Museum, inv. 71.PB.39.

35 At first I interpreted the difference in dress - and the hint of a beard in View 4 - as an indication that there are actually two models represented here and in the Brussels painting. But Elizabeth McGrath (email 22 July 2014) alerted me to the fact that the grey paint in the Brussels picture seems to have been roughly brushed over at a later stage, maybe not by Rubens.

36 In 1994, Held (1994:74-75) repeated his view that 'the picture is greatly overrated' and added that it is probably a later copy.

37 Peter Paul Rubens, Anthony van Dyck as a Youth (c. 1615). Oil on canvas. Fort Worth, Kimbell Art Museum (Van der Stighelen 1994:29, fig. 7).

38 Van Dyck was apprenticed to Hendrik van Balen in 1609 and trained under him for at least three to four years. Around 1615 or 1616 Van Dyck 
established his own workshop in Den Dom van Ceulen even before he was admitted as a master in the painter's guild of Antwerp in 1618 (Van der Stighelen 1994:21, 29).

39 Held (1982:151-52) states that the head in View 1 is twisted out of shape and that the forward extension of the mouth and chin section in View 3 is exaggerated. He further claims that the compositional concept is unsatisfactory. I would argue that compositional coherence is not a requirement in a study of separate tronies.

40 For a study of the African figures in the paintings of Van Dyck, see the article by Van Haute, 'Van Dyck and the trope of the African attendant: A matter of Christianity' (forthcoming).

41 See also Held (1980:599). Barnes (in Barnes et al. 2004:17) states that 'if Van Dyck did paint head studies especially for Rubens, he [Rubens] obviously employed them in his compositions'.

42 The document mentions: 'Vne quantite des visages au vif, sur toile, \& fonds de bois, tant de Mons. Rubens, que de Mons. Van Dyck' (quoted by Van Hout 2012:37).

43 Anthony van Dyck, Eleven Study Heads. Pen and brown ink, $13.7 \times 30.2 \mathrm{~cm}$. Chatsworth, the Devonshire Collection, inv. 682A (Van Hout 2012:37, ill. 28).

44 Such 'model-sheets' which combined various small sketches were made as a sort of visual catalogue and functioned as a memory aid (Van Hout 2012:37)

45 Follower of Van Dyck, Head of a Black Man (ca. 1640-50). Oil on wood, $42.5 \times 32.3 \mathrm{~cm}$. Frankfurt am Main, Städel Museum, inv. 889 (Tieze 2009:181-88).

46 An X-ray photograph of the Frankfurt panel reveals underneath the image of the black man the head of a young man who in type and posture recalls early self-portraits of Van Dyck (Tieze 2009:181, 188).

47 It should be noted that Larsen (1988, II:63-64, cat. no. 127) attributed another Head of a Black Man (oil on canvas, $47 \times 37 \mathrm{~cm}$, Oxford, Ashmolean Museum, inv. 177) to Van Dyck but it has subsequently been identified as a rather coarse copy after Van Dyck.

48 Peter Paul Rubens and Jan Brueghel, Nature Adorned (ca. 1615). Oil on panel, $106.7 \times 72.4$ $\mathrm{cm}$. Glasgow, Art Gallery and Museum. Already in this picture we see two faces from the Four Studies of the Head of a Black Man: the face of View 1 appears in the black figure climbing the tree in the top left corner while that of View 2 wearing a white headband is replicated in the figure seen to the right of Silenus in front of the high plinth carrying the herm-like statue (McGrath 2006:103).
49 Attributed to Jan I Brueghel, Studies of Heads. Oil on wood, $26.3 \times 32.2 \mathrm{~cm}$. Rohrau, Graf Harrach'sche Familiensammlung, inv. WF 285 (Menil Archive 04364).

50 Held (1980:600) maintains that the panel 'contains studies of a Negro's head in seven different poses' - excluding the possibility of more than one model.

51 Jan I Brueghel and Hendrick van Balen, Allegory of Winter (1616). Oil on copper, $57 \times 85 \mathrm{~cm}$. Neuburg an der Donau, Staatsgalerie (Ertz and Nitze-Ertz 2008-10:1092, 1339, cat. no. 524).

52 Peter Paul Rubens, Venus of the Night (ca. 1615). Oil on panel, $124 \times 98 \mathrm{~cm}$. Vaduz, Collection Liechtenstein, inv. G120 (McGrath 2008b:63-68, fig. 19).

53 Peter Paul Rubens, The Four Rivers (ca. 1615). Oil on canvas, $209 \times 284 \mathrm{~cm}$. Vienna, Kunsthistorisches Museum, inv. 526 (McGrath 2008b:60-63, fig. 18; Massing 2011:346349, fig. 231).

54 Jacob Jordaens, Study of a Black Man's Head (ca. 1620). Oil on canvas, $46.2 \times 31.2 \mathrm{~cm}$. Formerly New York, Estate of Jacob Goldschmidt (Held 1982, ill. XIII.5). Larsen (1988, II:64-65, cat. no. 129) catalogued it as a product of the Van Dyck workshop (ca. 1618).

55 Jacob Jordaens, The Rape of Europa (ca. 161516). Canvas, $273 \times 235 \mathrm{~cm}$. Berlin, Staatliche Museen (Vlieghe 1998: 35, fig. 29).

56 Jacob Jordaens, Allegory of Fruitfulness (ca. 1617). Oil on canvas, $250 \times 240 \mathrm{~cm}$. Munich, Alte Pinakothek, inv. 10411 (D'Hulst 1982:77, fig. 44).

57 See note 48.

58 Held (1980:612) also maintains that Jordaens painted the same black man in this study, explaining the differences between the two works in terms of style rather than physiognomy.

59 Jacob Jordaens, Apollo Flaying Marsyas (early 1620s). Oil on canvas, $146 \times 117 \mathrm{~cm}$. Antwerp, Huis Osterrieth (D'Hulst 1982:109, fig. 76).

60 Surely Jordaens must have made another tronie of this black man looking upwards, so that assistants in his workshop could integrate the motif in various compositions. This is also suggested by D'Hulst (1982:110).

61 Jacob Jordaens, Allegory of Fruitfulness (ca. 1623). Signed ORDA ... FECl. Oil on canvas, $180 \times 241 \mathrm{~cm}$. Brussels, Royal Museums of Fine Arts, inv. 120 (D'Hulst 1982:112, fig. 79).

62 Jacob Jordaens, The Apostle Peter Finding the Tribute Money in the Fish's Mouth (ca. 1623). Oil on canvas, $281 \times 468 \mathrm{~cm}$. Copenhagen, Statens Museum for Kunst, inv. 3198 (D'Hulst 1982:116, 117, 120, fig. 82).

63 Gaspar de Crayer, Head of a Young Moor (ca. 1631-35). Oil on canvas, $39.5 \times 32.7 \mathrm{~cm}$. 
Ghent, Museum of Fine Arts, inv. 0020049000 (Vlieghe 1972:131, cat. no. A65; McGrath 2008b:266).

64 According to Vlieghe (1972:131) the vigorous impasto and plasticity of the different details of the face are typical of De Crayer's style up until 1637 , suggesting a date of execution between 1631 and 1635.

65 Anthony Van Dyck, Portrait of Henrietta of Lorraine (1634). Oil on canvas, $213.4 \times 127$ $\mathrm{cm}$. London, the Iveagh Bequest, Kenwood, inv. 47 (Vlieghe 1994:206, fig. 8; Bindman 2010:250-253, fig. 136). Having fled from Nancy, Henrietta and her sister Margaret of Lorraine were in exile in Brussels in 1634 (Massing 2011:223-225).

66 Gaspar de Crayer, Charles V Exhorting His Great-Grandson Ferdinand to Follow His Example (1635). Oil on canvas, $455 \times 545 \mathrm{~cm}$. Ghent, Town Hall inv. 3571 (Vlieghe 1994:205, fig. 7).

67 Gaspar de Crayer, Raising of the Cross (163137). Oil on canvas, $400 \times 310 \mathrm{~cm}$. Rennes, Musée des Beaux-Arts, cat. no. 78. Originally made for the Capuchin Church in Bruges (Vlieghe 1972:131-132, cat. no. A66).

68 Anthony Van Dyck, Raising of the Cross (1631). Oil on canvas, size not mentioned. Kortrijk, Church of Our Lady (Vlieghe 1994:209, fig. 10).

\section{References}

Barnes, S.J., N. de Poorter, O. Millar and H. Vey. 2004. Van Dyck: A complete catalogue of the paintings. New Haven and London: Yale University Press.

Barnes, S.J. and A.K. Wheelock, Jr., eds. 1994. Van Dyck 350. Washington: National Gallery of Art.

Bindman, D. and H.L. Gates, Jr., eds. 2010. The image of the black in Western art: From the 'age of discovery' to the age of abolition. Artists of the Renaissance and Baroque. Vol. III, Part 1. Cambridge: Harvard University Press.

Blakely, A. 1993. Blacks in the Dutch world: The evolution of racial imagery in a modern society. Bloomington and Indianapolis: Indiana University Press.

Debrunner, H.W. 1979. Presence and prestige: Africans in Europe. A history of Africans in Europe before 1918. Basel: Basler Afrika Bibliographien.

De Clippel, K. 2006. Two sides of the same coin? Genre painting in the North and South during the sixteenth and seventeenth centuries. Simiolus 32(1):17-34.

Denucé, J. 1937. Afrika in de XVIde eeuw en de handel van Antwerpen. Antwerp: De Sikkel.
D'Hulst, R-A. 1954. De 'Morenkoppen': Enkele gegevens betreffende pedigree en physische toestand. Bulletin Koninklijke Musea voor Schone Kunsten van België (September):117-121.

D'Hulst, R-A. 1982. Jacob Jordaens. London: Sotheby Publications.

Earle, T.F. and K.J.P. Lowe, eds. 2005. Black Africans in Renaissance Europe. Cambridge: Cambridge University Press.

Erickson, P. 1993. Representations of blacks and blackness in the Renaissance. Criticism 35(4):499-528. www.martinsvianna.net (http:// www.iisr.nl/)

Ertz, K. and C. Nitze-Ertz. 2008-10. Jan Brueghel der Ä/tere (1568-1625): Kritischer Katalog der Gemälde. 4 vols. Lingen: Luca Verlag.

Goris, J.A. 1923. Uit de geschiedenis der vorming van het Amsterdamse stadsrecht: Slavernij te Antwerpen in de XVle eeuw. Bijdragen tot de Geschiedenis 15:541-544.

Goris, J.A. 1940. Lof van Antwerpen: Hoe reizigers Antwerpen zagen, van de vijftiende tot de twintigste eeuw. Brussel: Standaard.

Haarnack, C. and D. Hondius. 2008. 'Swart' (black) in the Netherlands: Africans and Creoles in the Northern Netherlands from the Middle Ages to the twentieth century. In Black is beautiful: Rubens to Dumas, ed. E. Schreuder and E. Kolfin, 89-106. Zwolle: Waanders.

Held, J. 1980. The oil sketches of Peter Paul Rubens: A critical catalogue. 2 vols. Princeton: Princeton University Press.

Held, J. 1982. The Four Heads of a Negro in Brussels and Malibu. In Rubens and his circle: Studies by Julius S. Held, ed. A.W. Lowenthal, D. Rosand and J. Walsh, Jr., 149-155. Princeton: Princeton University Press.

Held, J. 1994. Van Dyck's relationship to Rubens. In Van Dyck 350, ed. S.J. Barnes and A.K. Wheelock, Jr., 63-76. Washington: National Gallery of Art.

Jordan, A. 2005. Images of empire: Slaves in the Lisbon household and court of Catherine of Austria. In Black Africans in Renaissance Europe, ed. T.F. Earle and K.J.P. Lowe, 155180. Cambridge: Cambridge University Press.

Joubert, C., A.M. du Bourg and N. van Hout. 2012. Jacob Jordaens et son modèle Abraham Grapheus. Caen: Musée des Beaux-Arts de Caen. (Exhibition catalogue, Caen, Musée des BeauxArts de Caen, 11 May - 16 September 2012; Gand, Musée des Beaux-Arts/Museum voor Schone Kunsten, 29 September - 16 December 2012.)

Kaplan, P.H.D. 2010. Italy, 1490-1700. In The image of the black in Western art: From the 'age of discovery' to the age of abolition. Vol. III, Part 
1, ed. D. Bindman and H.L. Gates, Jr., 93-190. Cambridge: Harvard University Press.

Kolfin, E. 2008. Black models in Dutch art between 1580 and 1800: Fact and fiction. In Black is beautiful: Rubens to Dumas, ed. E. Schreuder and E. Kolfin, 71-87. Zwolle: Waanders.

Kolfin, E. 2010. Rembrandt's Africans. In The image of the black in Western art: From the 'age of discovery' to the age of abolition. Vol. III, Part 1, ed. D. Bindman and H.L. Gates, Jr., 271-306. Cambridge: Harvard University Press.

Larsen, E. 1988. The paintings of Anthony van Dyck. 2 vols. Freren: Luca Verlag.

Lowenthal, A.W., D. Rosand and J. Walsh, Jr., eds. 1982. Rubens and his circle: Studies by Julius S. Held. Princeton: Princeton University Press.

Massing, J.M. 2011. The image of the black in Western art: From the 'age of discovery' to the age of abolition. Europe and the world beyond. Vol. III, Part 2. Cambridge: Harvard University Press.

McGrath, E. 2008a. Rubens and his black kings. Rubens Bulletin (Koninklijk Museum voor Schone Kunsten Antwerpen) 2:87-101.

McGrath, E. 2008b. Goltzius, Rubens and the beauties of the night. In Black is beautiful: Rubens to Dumas, ed. E. Schreuder and E. Kolfin, 51-68, various catalogue entries. Zwolle: Waanders.

Meganck, T. 2007. Rubens on the human figure: Theory, practice and metaphysics. In Rubens: $A$ genius at work, ed. J. Vander Auwera and S. van Sprang, 52-64. Tielt: Lannoo.

Rubens, P.P. 1773. Théorie de la figure humaine. Paris: [sl].

Schreuder, E. 2008. 'Blacks' in court culture in the period 1300-1900: Propaganda and consolation. In Black is beautiful: Rubens to Dumas, ed. E. Schreuder and E. Kolfin, 21-31, various catalogue entries. Zwolle: Waanders.

Schreuder, E. and E. Kolfin, eds. 2008. Black is beautiful: Rubens to Dumas. Zwolle: Waanders. (Exhibition catalogue, Amsterdam, De Nieuwe Kerk, 26 July - 26 October 2008.)

Tieze, A. 2009. Flämische Gemälde im Städel Museum 1550-1800. Part I: Künstler von A-R. Frankfurt: Städel Museum.
Vander Auwera, J. 1981. Sebastiaen Vrancx (15731647) en zijn samenwerking met Jan I Brueghel (1568-1625). Jaarboek van het Koninklijk Museum voor Schone Kunsten Antwerpen 1981:135-151.

Vander Auwera, J. 2008a. Study of a black African man with a turban. In Black is beautiful: Rubens to Dumas, ed. E. Schreuder and E. Kolfin, 185. Zwolle: Waanders.

Vander Auwera, J. 2008b. Vier studies van het hoofd van een moor door Rubens in context. Unpublished lecture presented on the occasion of the exhibition 'Black is beautiful: Rubens tot Dumas', Amsterdam, 11 October 2008.

Vander Auwera, J. and S. van Sprang, eds. 2007. Rubens: A genius at work. Exhibition catalogue. Tielt: Lannoo. (Exhibition catalogue, Brussels, Royal Museums of Fine Arts of Belgium, 14 September 2007 - 27 January 2008.)

Van der Stighelen, K. 1994. Young Anthony: Archival discoveries relating to Van Dyck's early career. In Van Dyck 350, ed. S.J. Barnes and A.K. Wheelock, 17-46. Washington: National Gallery of Art.

Van Hout, N. 2012. Les tronies: L'emploi des têtes de caractères dans la peinture d'histoire flamande. In Jacob Jordaens et son modèle Abraham Grapheus, ed. C. Joubert, A.M. du Bourg and N. van Hout, 35-43. Caen: Musée des Beaux-Arts de Caen.

Vlieghe, H. 1972. Gaspar de Crayer, sa vie et ses oeuvres. 2 vols. Brussels: Arcade.

Vlieghe, H. 1994. Thoughts on Van Dyck's early fame and influence in Flanders. In Van Dyck 350, ed. S.J. Barnes and A.K. Wheelock, Jr., 199-220. Washington: National Gallery of Art.

Vlieghe, H. 1998. Flemish art and architecture 1585-1700. New Haven and London: Yale University Press.

Wheelock, A.K., Jr. 2005. Flemish paintings of the seventeenth century. The Collections of the National Gallery of Art, Washington. New York and Oxford: Oxford University Press. 